(Received October 4, 1981)

\title{
ACTIVATION VOLUME FOR THE DIFFUSION OF DYE MOLECULE IN POLY(ETHYLENE TEREPHTHALATE) ${ }^{*}$
}

\author{
By Jiro Seta and Taisuke Ito \\ (Faculty of Polytechnic Sciences, Kyoto Institute of Technology, \\ Matsugasaki, Kyoto 606)
}

\section{Synopsis}

Pressure effect on the diffusion coefficient $D$ of nine disperse dyes in poly (ethylene terephthalate) (PET) sheet was investigated at $130^{\circ} \mathrm{C}$ under pressures up to $1 \mathrm{kbar}$ by the multiple membrane method. The values of $\ln D$ showed linear decrease with increasing pressure, giving the activation volume $\Delta V^{\ddagger}$ for diffusion, $64-123 \mathrm{~cm}^{3} / \mathrm{mol}$ for p-nitroaniline (pNA) and C.I. Disperse Blue 1 (DB1), respectively. The molecular volumes of the penetrants in crystalline state were evaluated from the density measurements, $x$-ray data and the van der Waals contact models of the molecules. For example, the molecular volumes of $\mathrm{pNA}$ and $\mathrm{DB1}$ were 99 and $182 \mathrm{~cm}^{3} / \mathrm{mol}$, respectively. The results of $\Delta V^{\ddagger}$ were now compared with the molecular volumes of the penetrants. It was found that $\Delta V^{\ddagger}$ increased almost linearly with increasing molecular volume. It was further demonstrated that the anthraquinone derivatives needed larger $\Delta V^{\ddagger}$ than the azo derivatives compared at the same molecular volume. These as well as the differences between the observed $\Delta V^{\neq}$and the molecular volumes of the penetrants were discussed from the viewpoint of the free volume theory.

\section{INTRODUCTION}

The activation volume $\Delta V^{\ddagger}$ for the diffusion of dye in a polymeric solid can be obtained ${ }^{1-3)}$ by measuring the effect of hydrostatic pressure $(P)$ on the diffusion coefficient $(D)$ of the dye molecule (penetrant molecule) according to

$$
\Delta V^{\ddagger}=-R T(\partial \ln D / \partial P)_{T},
$$

where $R$ and $T$ are the gas constant and absolute temperature, respectively. In application of eq. (1) to a system composed from a dye dissolved in water (solvent) plus a polymeric solid material, $\Delta V^{\mp}$ may be written as

$$
\Delta V^{*}=\Delta V_{\mathrm{EH}}^{\neq}+\Delta V_{\mathrm{D}}^{\neq}+\Delta V_{\mathrm{P}}^{\neq}+\Delta V_{\mathrm{S}}^{\neq},
$$

where $\Delta V_{E H}^{\neq}$is the positive local volume change ${ }^{4)}$ allowing accommodation of the diffusing penetrant which results from fluctuation of the Eyring's hole (EH), $\Delta V_{D}^{\ddagger}, \Delta V_{\mathrm{p}}^{\ddagger}$ and $\Delta V_{\mathrm{s}}^{\ddagger}$ are the associated changes of the partial volumes occupied by, respectively, the penetrant, the polymer and the

\footnotetext{
* Studies on the Physical Chemistry of Dyeing under High Hydrostatic Pressure. IV.
}

solvent in the swollen polymer matrix. Such local volume changes are referred only to those that are involved in the diffusion of the penetrant, based on one mole of the penetrant. Since the primary step in the dye diffusion in a solid or in a quasicrystalline liquid can be imagined ${ }^{2,5-6)}$ to proceed through the displacement of a penetrant from a normal adsorbed site into a high energy hole, the rate of the process will be governed by the ease with which the EH's can be formed. If the EH formation is assumed to be the rate-determining process, then $\Delta V^{\ddagger}$ in eq. (2) is approximated by

$$
\Delta V^{\neq}=\Delta V_{\mathrm{EH}}^{\neq} \text {. }
$$

From eq. (3), it is expected that larger dye molecule needs larger $\Delta V^{\mp}$ and suffers larger pressure effect, because larger penetrant requires larger $\mathrm{EH}$ for accommodation. The purpose of the present paper is to refer $\Delta V^{\ddagger}$ obtained by eq. (1) to the molar volume of the penetrant $(V)$ and to clarify the relationship between them.

For the purpose of introducing eq. (1) into the present study, the followings are desirable to be taken into account. First, the $\Delta V^{\ddagger}$ obtained from 
eq. (1) is dependent on the free volume initially present in the polymer matrix ${ }^{1,3,7)}$. This is because the activation volume gives the excess free volume of the transition state over the free volume present in the initial state, considered within the range of the local volume ${ }^{8-9}$ ). It is evident that both the $\Delta V^{\ddagger}$ and the initial free volume contribute without distinction to the formation of the $\mathrm{EH}$ for accommodating the diffusing penetrant, whether or not the free volume was initially present or formed at the activated state. In order to minimize the swelling by water and thus the contribution by the initial free volume which will leave more or less ambiguous room in correlating $\Delta V^{\ddagger}$ with $V$ of the penetrant, it is necessary to use a hydrophobic polymer material such as polyethylene, PET, etc. Secondly, the penetrant substance should also be hydrophobic which makes special bonds such as electrostatic-, hydrogen- and coordination-bonds, etc. with the polymer molecule as least as possible. This is for minimizing the contributions from the terms $\Delta V_{\mathrm{D}}^{\neq}, \Delta V_{\mathrm{P}}^{\ddagger}$ and $\Delta V_{\mathrm{s}}^{\neq}$which have been neglected in obtaining eq. (3). The above situation led us to study the diffusion of various disperse dyes in PET at $130^{\circ} \mathrm{C}$ under high hydrostatic pressure.

\section{EXPERIMENTAL}

A PET sheet supplied by courtesy of Toray Industries, Inc. (grade\#6) was used. This is the same sample as was used in a previous paper ${ }^{1}$. The sheet was heat-treated in water at $160^{\circ} \mathrm{C}$ for an hour in the same way as previously described. The density of the heat-treated and dried sample was $1.408 \mathrm{~g} / \mathrm{cm}^{3}$ at $30^{\circ} \mathrm{C}$ and the thickness in the wet state was $6.3 \mu \mathrm{m}$. For the penetrants, p-nitroaniline (pNA), p-aminoazobenzene (pAAB), 4'nitro-4-dimethylaminoazobenzene (4' $\mathrm{N}-4 \mathrm{DMAAB}$ ), C.I. Disperse Orange 1 (DO1), C.I. Disperse Red 7 (DR7), 1-aminoanthraquinone (1AA), C.I. Disperse Red 15 (DR15), C.I. Disperse Violet 1 (DV1) and C.I. Disperse Blue 1 (DB1) were used. Among these, pNA, pAAB, 4'N-4DMAAB, 1AA, DR15 and DV1 were commercial grade chemical reagents, while DO1, DR7 and DB1 were kindly supplied in the form of color cake by Mitsubishi Kasei Kogyo Co. These penetrant samples were purified by repeated recrystallizations to give single crystals in size which enabled density measurement by floating method. Melting points were determined on a Yanagimoto Model MP-S3 micromelting apparatus. Table $I$ includes these characterizations. Aqueous solutions of the penetrants were prepared according to the last column of Table I. For pNA and $\mathrm{PAAB}$, the crystals were completely dissolved in water to give solutions at room temperature. For the other crystals, the listed recipe was above the saturation and the undissolved crystals remained during the experiment. The measurement of $D$ of the penetrant in the PET sheet was carried out at $130^{\circ} \mathrm{C}$ under high pressures up to $1 \mathrm{kbar}$ by the use of the multiple membrane method. The apparatus, the experimental procedure and the analysis by Matano's formula have been described in detail in the previous paper ${ }^{1,7)}$. The accurate determination of the diffusion time was successful by the method described in Figure 1 of ref. (7) where the polypropylene tube was not used in the present study.

by the use of Matano's multiple membrane method. The apparatus and the experimental procedure have been described in detail in the previous paper').

\section{THE VOLUME OF THE PENETRANT MOLECULE}

In order to evaluate $V$ of the penetrant, the molar volume in the crystalline state was used ${ }^{1)}$. According to whether the crystalline density was supplied by dilatometry or from the $\mathbf{x}$-ray unit cell dimension, $V_{\rho}$ or $V_{\mathrm{x}}$ can be calculated for $V$ by, respectively,

$$
\begin{aligned}
& V_{\rho}\left(\mathrm{cm}^{3} / \mathrm{mol}\right)=M / \rho \\
& V_{\mathbf{x}}\left(\mathrm{cm}^{3} / \mathrm{mol}\right)=0.6022 v / Z,
\end{aligned}
$$

where $M$ is the molecular weight, $\rho$ the CGS dilatometric density, $v$ the volume of the unit cell expressed in $\AA^{3}, Z$ the number of the molecules contained in the unit cell. The crystal structures determined by $x$-ray analysis, by themselves, have been so determined that the data of $v$ and $Z$ were compatible with the dilatometric density.

It is the real situation, however, that one has often to use a dye having known chemical constitution for which neither $V_{\mathbf{x}}$ nor $V_{\rho}$ is available. In this case, some conventional method was necessary to evaluate $V$. This was settled by the 
Table I Characterization of disperse dyes

\begin{tabular}{|c|c|c|c|c|}
\hline $\begin{array}{l}\text { Disperse dyes } \\
\text { (Abbreviation) }\end{array}$ & Chemical constitution & $\begin{array}{l}\text { m.p. } \\
\left({ }^{\circ} \mathrm{C}\right)\end{array}$ & $\begin{array}{l}\text { Density } \\
\text { at } 30^{\circ} \mathrm{C} \\
\left(\mathrm{g} / \mathrm{cm}^{3}\right)\end{array}$ & $\begin{array}{l}\text { Preparation of } \\
\text { the aq. solution } \\
\text { (mg } / 1 \text { ) }\end{array}$ \\
\hline $\begin{array}{l}\mathrm{p}-\text {-Nitroaniline } \\
(\mathrm{pNA})\end{array}$ & $\mathrm{O}_{2} \mathrm{~N}-\mathrm{C}$ & 145 & 1.395 & 800 \\
\hline $\begin{array}{l}\text { p-Aminoazobenzene } \\
\quad(p A A B)\end{array}$ & -(O) $-\mathrm{NH}_{2}$ & 127 & 1.196 & 20 \\
\hline $\begin{array}{l}\text { 4'-Nitro-4-dimethyl- } \\
\text { aminoazobenzene } \\
\text { (4'N-4DMAAB) }\end{array}$ & (a) $\left.-\mathrm{NCH}_{3}\right)_{2}$ & 235 & - & (50) \\
\hline $\begin{array}{l}\text { C.1, Disperse Orange 1 } \\
\text { (DO1) }\end{array}$ & - (O) $-N-0$ & 162 & 1.325 & (50) \\
\hline $\begin{array}{l}\text { C.I. Disperse Red } 7 \\
\text { (DR7) }\end{array}$ & 5) $-\mathrm{N}\left(\mathrm{C}_{2} \mathrm{H}_{4} \mathrm{OH}\right)_{2}$ & 192 & 1.461 & (50) \\
\hline $\begin{array}{l}\text { 1-Aminoanthraquinone } \\
\text { (1AA) }\end{array}$ & & 250 & 1.434 & (50) \\
\hline $\begin{array}{l}\text { C.1. Disperse Red } 15 \\
\text { (DR15) }\end{array}$ & & 219 & 1.487 & $(50)$ \\
\hline $\begin{array}{l}\text { C.I. Disperse Violet } 1 \\
\text { (DV1) }\end{array}$ & & 267 & 一 & (50) \\
\hline $\begin{array}{l}\text { C.I. Disperse Blue } 1 \\
\text { (DB1) }\end{array}$ & & $>300$ & - & (50) \\
\hline
\end{tabular}

$V_{\mathrm{w}}$ as described in the following. It is well known that the dye molecule is very often a flat molecule because of the network of the conjugated chain within it. Neglecting the effect of the thicker knobs due to sulfonic anions $\left(-\mathrm{SO}_{3}^{-}\right)$in some cases, the volume of a dye molecule may approximately be given by the area of the silhouette $\left(A_{\mathrm{w}}\right)$ of the flat molecule multiplied by the thickness. because of the network of the conjugated double bonds chain within it. Neglecting the effect of the thicker knobs due to sulfonic anions $\left(-\mathrm{SO}_{3}^{-}\right)$in some cases, the volume of a dye molecule may approximately be given by the area of the silhouette $\left(A_{W}\right)$ of the flat molecule multiplied by the thickness. This volume, converted to the value per mole of the molecule, was defined as $V_{w}$. The silhouette This volume, converted to the value per mole of the molecule, was defined as $V_{\mathrm{w}}$. The silhouette can be drawn by making the van der Waals (vdW) contact model of the molecule according to the description by Kitaigorodskii ${ }^{10)}$, while the thickness, in the case of dye molecule, may be roughly put equal to the thickness of the benzene ring ${ }^{11)}$, i.e. $3.70 \AA$. The silhouettes of some twenty aromatic compounds selected from the textbook by Kitaigorodskii ${ }^{10)}$ which are essentially similar in the structure to the dye molecule were drawn as shown in Figure 1 in which examples for transazobenzene and anthraquinone were given. $A_{W}$ for the silhouette was calculated by dividing it into several simple geometrical figures. In Table II were listed $V_{x}$ and $V_{W}$ for those aromatic compounds for which the $x$-ray data, including bondlengths and bond-angles, were all available ${ }^{10}$. Here the $V_{\mathrm{W}}$ was obtained from eq. (6),

$$
V_{\mathrm{W}}\left(\mathrm{cm}^{3} / \mathrm{mol}\right)=N_{\mathrm{A}}\left(3.49 \times A_{\mathrm{W}}\right),
$$

where $N_{\mathrm{A}}$ is the Avogadro number and the volume term in the right hand side, $3.49 \times A_{W}$, was expressed in $\mathrm{cm}^{3}$. In eq. (6), a value of $3.49 \AA$ instead of $3.70 \AA$ was used for the thickness, because the latter value was found to be a little too much overestimated to obtain $V_{w}$ which agrees with $V_{\mathrm{x}}$. The relationship between $V_{\mathrm{W}}$ and $V_{x}$ for the above aromatic compounds was given in Figure 2 where the points of $V_{w}$ are seen to come on the $45^{\circ}$ line of $V_{w}=V_{x}$. From Figure 2, it is justifiable that the volume of a dye molecule 


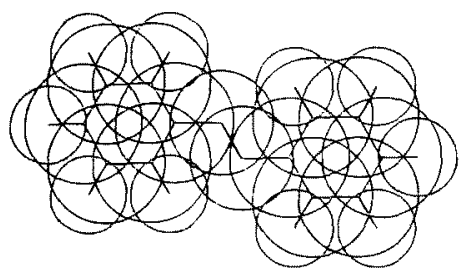

(a) trans-Azobenzene

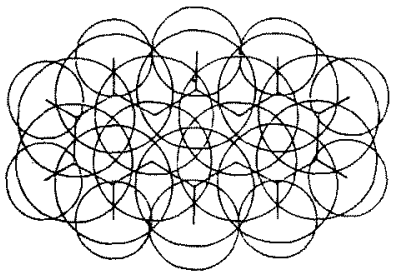

(b) Anthraquinone

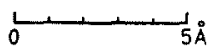

Fig. 1 Drawing of the silhouettes of the van der Waals contact model for trans-azobenzene (a) and anthraquinone (b). All the data for the bond-lengths, bond-angles and the van der Waals radii were referred to Kitaigorodskii ${ }^{10)}$.

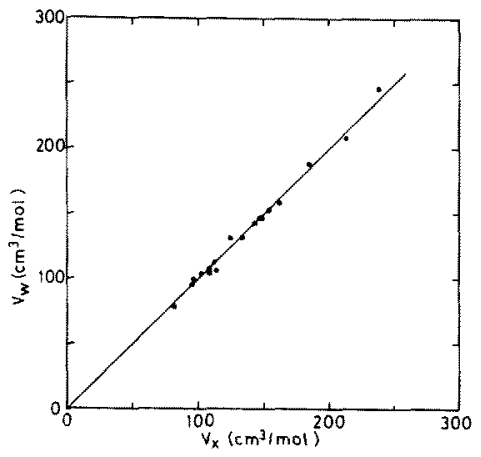

Fig. 2 Plots of $V_{\mathrm{w}}$ vs. $V_{\mathrm{x}}$. The solid line indicates $45^{\circ}$ line.

Table II Twenty aromatic compounds selected from Kitaigorodskii ${ }^{10)}$ having similar structures to the disperse dye for the purpose of examining relationship between $V_{\mathrm{W}}$ and $V_{\mathrm{x}} . A_{\mathrm{W}}$ denotes the area of the silhouette of the flat van der Waals contact model of the molecule.

\begin{tabular}{rlrrrr}
\hline No. & \multicolumn{1}{c}{ Compound } & M.W. & $\begin{array}{r}V_{\mathbf{x}} \\
\left(\mathrm{cm}^{3} / \mathrm{mol}\right)\end{array}$ & $\begin{array}{r}A_{\mathrm{W}} \\
\left(\AA^{2}\right)\end{array}$ & $\begin{array}{r}V_{\mathrm{W}} \\
\left(\mathrm{cm}^{3} / \mathrm{mol}\right)\end{array}$ \\
\hline 1 & p-Benzoquinone & 108.10 & 81.4 & 37.1 & 78 \\
2 & p-Dimethoxybenzene & 138.17 & 114.4 & 50.6 & 106 \\
3 & p-Toluidine & 107.16 & 94.9 & 45.2 & 95 \\
4 & p-Dinitrobenzene & 168.11 & 101.8 & 49.6 & 104 \\
5 & m-Dinitrobenzene & 168.11 & 108.6 & 49.6 & 104 \\
6 & Diphenyl & 154.21 & 124.9 & 62.4 & 131 \\
7 & p-Diphenylbenzene & 230.31 & 185.0 & 89.8 & 188 \\
8 & P.p'-bis-(Phenyl)-diphenyl & 306.41 & 238.4 & 117.1 & 246 \\
9 & Stilbene & 180.25 & 154.1 & 72.9 & 153 \\
10 & trans-Azobenzene & 182.23 & 148.6 & 70.0 & 147 \\
11 & cis-Azobenzene & 182.23 & 149.2 & 70.0 & 147 \\
12 & Naphthalene & 128.17 & 108.2 & 50.9 & 107 \\
13 & $\alpha$-Naphthol & 144.17 & 112.0 & 53.6 & 112 \\
14 & P-Naphthol & 144.17 & 111.7 & 53.6 & 112 \\
15 & 1,5-Dinitronaphthalene & 218.17 & 133.6 & 62.5 & 131 \\
16 & Anthracene & 178.23 & 142.8 & 67.8 & 142 \\
17 & Anthraquinone & 208.22 & 146.8 & 69.7 & 146 \\
18 & 1,2,5,6-Dibenzanthracene & 278.35 & 213.4 & 99.1 & 208 \\
19 & p-Nitroaniline & 138.12 & 96.5 & 47.2 & 99 \\
20 & p-Aminoazobenzene & 197.23 & 162.1 & 75.4 & 158 \\
\hline & & & & & \\
\hline
\end{tabular}


for which both $V_{\rho}$ and $V_{\mathrm{x}}$ are unknown can safely be estimated from their $V_{W}$ 's, so long that the molecule is decorated with not many side groups and flexible bridges. In Figure 3 were drawn the silhouettes of the vdW model for the penetrants used in the present work, where, for DR7, the two $-\mathrm{CH}_{2}-\mathrm{CH}_{2}-\mathrm{OH}$ side groups were not drawn and, instead, the volume increments ${ }^{10)}$ due from four $\mathrm{CH}_{2}$ groups $\left(16.6 \AA^{3}\right.$ per $\left.\mathrm{CH}_{2}\right)$ and two $\mathrm{OH}$ groups $\left(10.7 \AA^{3}\right.$ per $\left.\mathrm{OH}\right)$ were added to obtain $V_{W}$. In Table III, the $V_{w}$ 's obtained from Figure 3 were compared with $V_{D}$ 's for those penetrants whose densities were successfully known from the density measurements of the single crystals. A good agreement within $3 \%$ was found between $V_{\mathrm{W}}$ and $V_{o}$. The reason for the discrepancy $(9 \%)$ found for DR7 is not very clear, but it is likely that the two tails of the $-\mathrm{CH}_{2}-\mathrm{CH}_{2}-\mathrm{OH}$ groups reduce the packing efficiency in the crystal structure of DR7 which causes larger $V_{o}$. In the present paper, $V_{\mathrm{W}}$ will be used in preference to both $V_{\mathrm{x}}$ and $V_{\Delta}$ from the viewpoint to give consistency throughout the discussion.

It is worthwhile giving a comment here that the net volume of the vdW contact model of a molecule is related with $V_{\mathrm{x}}, V_{\rho}$ or $V_{\mathrm{W}}$ through the packing density $k$ defined by the relationship,

$$
\begin{gathered}
k=\text { (the total volume of the vdW contact } \\
\text { models of the } Z \text { molecules) } / v \text {. }
\end{gathered}
$$

Since the values of $k$ for most organic molecular crystals range ${ }^{10)}$ between 0.7 and $0.8, V_{x}, V_{\rho}$ or the above estimated $V_{W}$ is larger by $20-30 \%$ than the net vdW contact model of the molecule. The excess volume is the dead space which arises when the molecules are packed in the crystalline state.

\section{RESULTS AND DISCUSSION}

The diffusion profile for DB1 in PET sheet obtained at $130^{\circ} \mathrm{C}$ and 800 bar was shown as an example in Figure 4. The $D$-value was calculated ${ }^{12}$ ) by Matano's method as a function of the relative concentration $C=c / c_{0}$, where $c$ and $c_{0}$ are the concentrations of the adsorbed dye at the surface and at the depth $x$ from the surface, respectively. Except for the steep increase of $D$ seen at high $C$ region, $D$ remains almost constant with the variation of $C$. The reason for the increase of $D$ at $C>0.8 \sim 0.9$ was ascribed in the previous
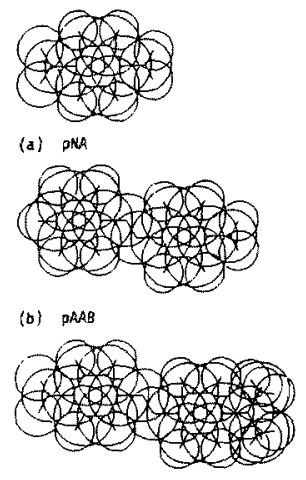

(c) 4 'N-4OMAAB

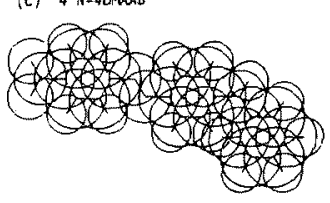

(d) 001

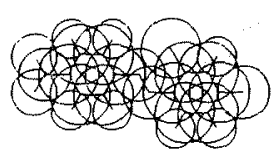

(e) $\mathrm{DR} 7$

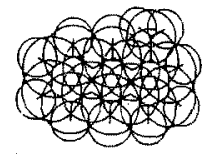

(f) IAA

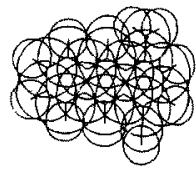

(g) DRI5

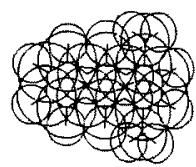

(h) DYI

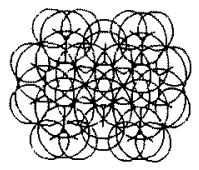

(i) OBI

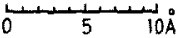

Fig. 3 The silhouettes of the van der Waals contact model for the nine penetrants used in the present study. The data for constructing the model were the following ${ }^{10)}$. Van der Waals radii $(r): r_{\mathrm{C}}=1.8 \AA, r_{\mathrm{H}}=1.17 \AA$, $r_{\mathrm{o}}=1.36 \AA, r_{\mathrm{N}}=1.57 \AA, r_{\mathrm{Cl}}=1.78 \AA$. Bond lengths: $\mathrm{C}-\mathrm{C}$ (aromatic ring) $=1.4 \AA, \mathrm{C}-\mathrm{N}$ (aromatic) $=1.43 \AA, C-N$ in the amino group bonded directly to the aromatic ring $=1.37 \AA, \quad \mathrm{N}-\mathrm{H}=1.02 \AA, \quad \mathrm{N}-\mathrm{O}$ (nitro) $=1.24 \AA, \quad \mathrm{C}-\mathrm{Cl}=1.7 \AA, \quad \mathrm{N}=\mathrm{N}=1.25 \AA$, $\mathrm{C}=\mathrm{O}$ (quinone) $=1.15 \AA$. An ideal angle of $120^{\circ}$ was used for all the bond angles. The two $-\mathrm{CH}_{2}-\mathrm{CH}_{2}-\mathrm{OH}$ groups were removed from DR7 (see text).

paper $^{12)}$ to an artifact due to the inherent character of the exponential function used to fit to the observed points of the profile and seems not essential. As shown in Figure 4, the $D$ value defined at $C$ dividing the area under the diffusion profile into two equal areas by the horizontal line parallel to the distance axis was represented with $\bar{D}$ (given in Figure 4 by the square mark) and will be used in the following discussion. The $\bar{D}$ values in PET sheet at $130^{\circ} \mathrm{C}$ under various high hydrostatic pressures were listed in Table IV for the 
Table III Data for $\Delta V^{\ddagger}$, atmospheric pressure diffusion coefficient $\bar{D}_{0}, A_{\mathrm{W}}, V_{\mathrm{W}}$ and $V_{o}$ for various disperse dyes

\begin{tabular}{lcccccc}
\hline \multicolumn{1}{c}{ Disperse Dyes } & M.W. & $\begin{array}{c}\bar{D}_{\mathbf{0}} \\
\left(10^{-8} \mathrm{~cm}^{2} / \mathrm{min}\right)\end{array}$ & $\begin{array}{c}A_{\mathrm{w}} \\
\left(\AA^{2}\right)\end{array}$ & $\begin{array}{c}V_{\mathrm{w}} \\
\left(\mathrm{cm}^{3} / \mathrm{mol}\right)\end{array}$ & $\begin{array}{c}V_{o} \\
\left(\mathrm{~cm}^{3} / \mathrm{mol}\right)\end{array}$ & $\begin{array}{c}\Delta V^{\ddagger} \\
\left(\mathrm{cm}^{3} / \mathrm{mol}\right)\end{array}$ \\
\hline p-Nitroaniline & 138.12 & 32.2 & 47.2 & 99.3 & 99.0 & 64 \\
p-Aminoazobenzene & 197.23 & 16.8 & 75.5 & 158.6 & 164.9 & 83 \\
4'-Nitro-4-dimethyl- & 270.32 & 3.12 & 92.8 & 194.9 & - & 106 \\
aminoazobenzene & & & & & & \\
C.I. Disperse Orange 1 & 318.36 & 3.20 & 108.6 & 228.3 & 240.3 & 116 \\
C.I. Disperse Red 7 & 364.79 & 1.46 & 83.5 & $228.3 *$ & 249.7 & 103 \\
1-Aminoanthraquinone & 223.23 & 6.84 & 73.6 & 154.6 & 155.7 & 87 \\
C.I. Disperse Red 15 & 239.23 & 5.77 & 76.0 & 159.8 & 160.9 & 110 \\
C.I. Disperse Violet 1 & 238.25 & 5.17 & 77.9 & 163.7 & - & 109 \\
C.I. Disperse Blue 1 & 268.28 & 2.58 & 86.6 & 181.9 & - & 123 \\
\hline
\end{tabular}

* Volume increments from two $-\mathrm{CH}_{2}-\mathrm{CH}_{2}-\mathrm{OH}$ groups were added.

Table IV $\bar{D}$ data at $130^{\circ} \mathrm{C}$ under various pressures

(a) $\bar{D}\left(10^{-7} \mathrm{~cm}^{2} / \mathrm{min}\right)$

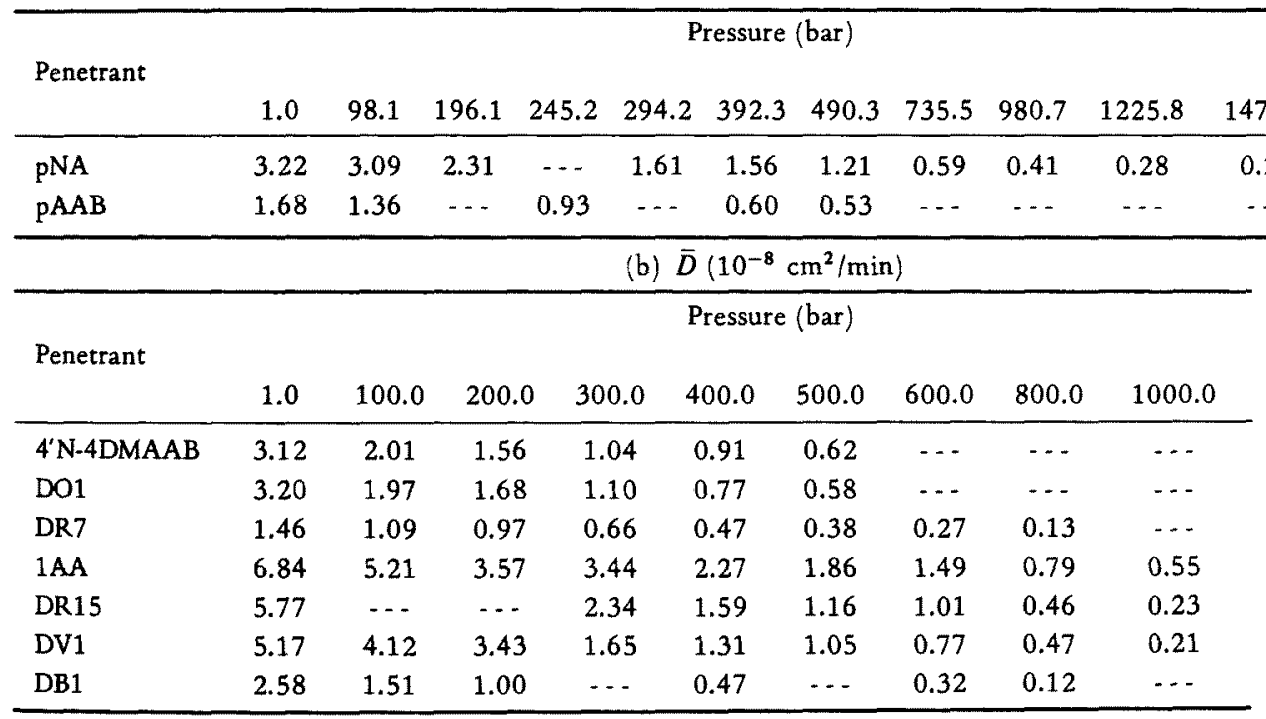

nine penetrants. Evidently, the pressure effect on the diffusion of the penetrant in PET was large. It was found that a pressure of 500 bar reduced $\bar{D}$ down to $38 \%$ for $\mathrm{pNA}$ and $18 \%$ for DO1 of the values at the ambient pressure. Such pressure effects are essentially in accordance with the criterion by eq. (1) operating by a positive $\Delta V^{\#}$ The diffusivity of the penetrant was the most large for pNA whose molecular volume is the smallest among the nine penetrants. As shown in Table III, it is interesting to note that the value of $\bar{D}$ obtained at atmospheric pressure, denoted with $\bar{D}_{\mathbf{0}}$, decreases with an increase of the molecular volume of the penetrant; particularly, the order of decrease is consistent with the increase of $V$ when the comparison is limited within either of the groups of the azo or the anthraquinone dyes. However, such consistency does not hold when the comparison is made among all the nine penetrants.

In order to evaluate $\Delta V^{\ddagger}, \ln \bar{D}$ for each penetrant was plotted against pressure in Figure 5. In 


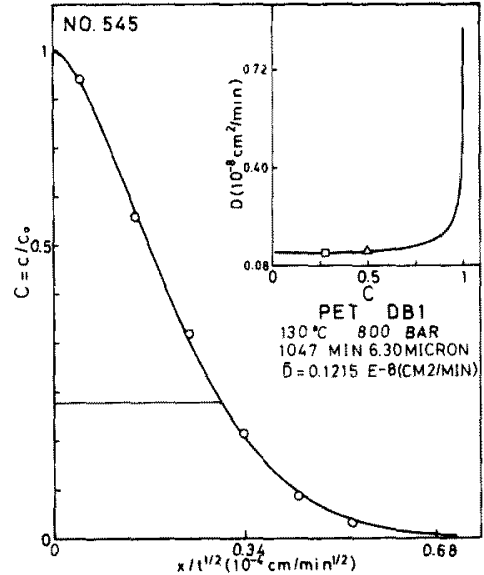

Fig. 4 Profile of the diffusion of DB1 in PET from aqueous solution at $130^{\circ} \mathrm{C}$ and 800 bar. The inserted diagram gives dependence of the diffusion coefficient $D$ on the relative concentration $C$ where the symbol $\triangle$ indicates $C=0.5$. For the symbol $\square$, refer to the text.

spite of the scatter of the points which could not be removed, the results were approximated by linear relationships drawn in Figure 5. Because the free volume in the PET sheet should decrease with increasing pressure, some nonlinear relationship between $\ln \bar{D}$ and $P$ may be expected. If so, the application of eq. (1) which originates from the thermodynamic considerations ${ }^{4,9)}$ should be valid only at $P \rightarrow 0$. However, reviewing all the data in our study which included not only PET but Nylon $6^{9)}$ and regenerated cellulose (cellophane) ${ }^{7}$, no indication for a nonlinear relationship has been found within the experimental error. This is also the case in the study by Assink ${ }^{3)}$ who measured the pressure effect $(2000 \mathrm{bar})$ on the diffusion of dichlorodifluoromethane in poly(dimethyl siloxane) by means of NMR pulsed-field-gradient method. A small, non-negligible curvature might have been masked and missed by the experimental error in our and Assink's studies.

Apart from the above points, $\Delta V^{\neq}$'s for diffusion could be obtained from the slopes of the linear lines in Figure 5 by the least squares method and were listed in Table III. In order to see the correlation between $\Delta V^{\neq}$and the volume of the penetrant molecule, $\Delta V^{*}$ was plotted against $V_{\mathrm{W}}$

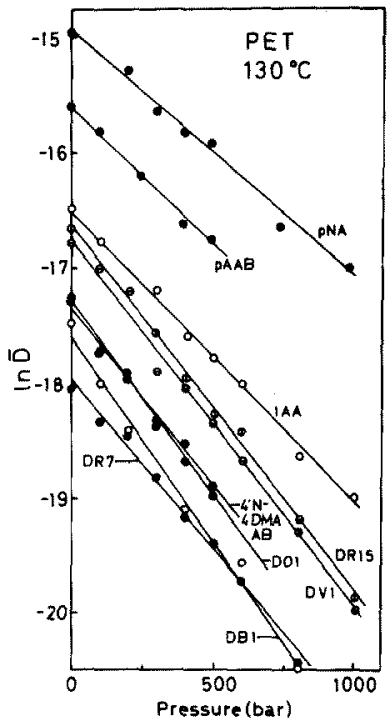

Fig. 5 Plots of $\ln \bar{D}$ vs. pressure for various disperse dyes.

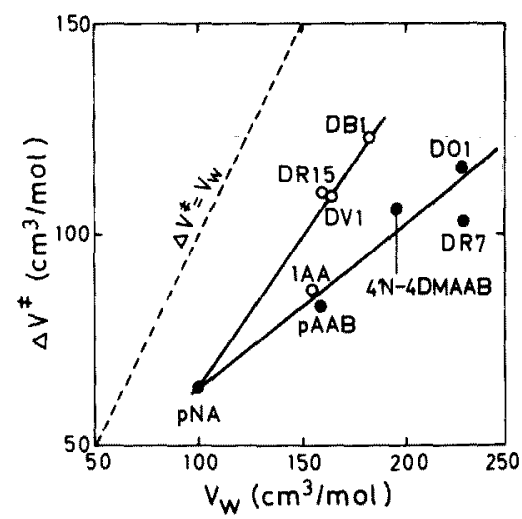

Fig. 6 Relationship between $\Delta V^{\ddagger}$ for diffusion and the molecular volume $\left(V_{W}\right)$ of the penetrant.

in Figure 6. In Figure 6, there may be noted two points; first, $\Delta V^{\ddagger}$ increases with increase in $V_{W}$ with an apparently linear relationship, and second, the points for the anthraquinone derivatives fell on a line separating from that for the azo derivatives, the slope against increase in $V_{W}$ in the former being larger than for the latter. These will be discussed in the following.

The fact that $\Delta V^{\neq}$increases with increasing $V_{W}$ may be self-evident from a simple consideration 
that the larger penetrant needs the larger EH. However, the fact that such a simple consideration could be applicable should nevertheless be pointed out here, since it means that the contributions of $\Delta V_{\mathrm{p}}^{\neq}, \Delta V_{\mathrm{p}}^{\neq}$and $\Delta V_{\mathrm{s}}^{\neq}$in eq. (2) are not effective, as was assumed in obtaining eq. (3). On the other hand, it is not simple to explain the linear relationships. At first, in Figure 6, one can note the difference along the direction of the ordinate axis from the two solid experimental lines to the dotted line representing $\Delta V^{\ddagger}=V_{\mathrm{w}}$. On the basis of the consideration in one of the preceding sections, these differences should be ascribed to the initial free volume inherently distributed in the solid PET material held in water at $130^{\circ} \mathrm{C}$.

Now, let assume, as schematically illustrated in Figure 7, four PET chains, each of which consisted from 1.75 chemical repeating units ( $19 \AA$ long) along the chain, are associated with the diffusion of one pNA - they are the "neighbors" accommodating one pNA molecule and give the range of the local volume to be used to define $\Delta V^{\mp}$ The size of a pNA molecule was evaluated to be $9.5 \AA$ (length) $\times 6.5 \AA$ (width) $\times 3.7 \AA$ (thickness) from Figure 3 (a), while the PET chains, if aggregated in the crystalline state, have spacing ${ }^{13)}$ between their chain-axes ranging from 4.6 to $6.0 \AA$ and length of $19 \AA$ (see above). The spacing between chains will expand to some degree in the noncrystalline region. The illustration of Figure 7 was drawn to scale. The hole drawn with dotted line and viewed along the chain-axis may be justifiable to be of a size that can accommodate one pNA molecule.

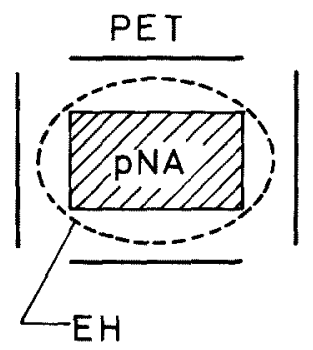

Fig. 7 The pNA molecule accommodated in an EH which in turn is surrounded by PET chains, the "effective" neighbors determining local volume expansion during activation for diffusion.
From the above consideration, $1345.1 \mathrm{~g}$ of PET, corresponding to 7 moles of the repeating chemical unit, should supply at $130^{\circ} \mathrm{C}$ the free volume of $V_{\mathrm{W}}-\Delta V^{\neq}=36 \mathrm{~cm}^{3}$ per mole of pNA as evaluated from Figure 6. It is well known that the WLF relationship predicts $2.5 \%$ by volume of free volume at the glass-temperature $\left(T_{\mathrm{g}}\right)$ under the atmospheric pressure. Calculated from this prediction, the above weight of PET is estimated to contain about $25 \mathrm{~cm}^{3}$ of free volume at $T_{g}$, assuming the density of the noncrystalline PET material to be $1.34 \mathrm{~g} / \mathrm{cm}^{3}{ }^{14}$ ). According to the recent ${ }^{13} \mathrm{C}$ high-resolution NMR studies by Kitamaru and co-workers ${ }^{15}$ ), it was clearly demonstrated that the thermal motion, having the correlation time of $10^{-5}-10^{-6} \mathrm{sec}$, initiates at $125^{\circ} \mathrm{C}$ in the phenyl carbon atoms of the noncrystalline PET chain. If this temperature was taken as $T_{\mathrm{g}}$ of PET on one hand, and if its water-induced shift was evaluated to be $20^{\circ} \mathrm{C}$ from the diffusion study by Dumbleton et al. ${ }^{16)}$ on the other, and if, further, the difference between the expansion coefficients for the rubbery and the glassy PET's at $T_{\mathrm{g}}$ is assumed ${ }^{6)}$ to be 4.8 $\times 10^{-4}$ degree $^{-1}$, the above weight of PET held in water at $130^{\circ} \mathrm{C}, 25^{\circ} \mathrm{C}$ above $T_{g}$, is calculated to contain about $37 \mathrm{~cm}^{3}$ of the free volume in good agreement with the expected value of $36 \mathrm{~cm}^{3}$. Since, however, $T_{\mathrm{g}}$ depends quite significantly on the method of measurement and, moreover, the model employed in Figure 7 is a crude one and not quantitative, our conclusion obtained above should be regarded as giving an essential support to our scheme of consideration. The linear increase of the $\Delta V^{\ddagger}$ with increasing $V_{\mathrm{W}}$ may consequently be understandable if the difference between $\Delta V^{\ddagger}$ and the dotted $\Delta V^{\ddagger}=V_{\mathrm{W}}$ line increases linearly with increasing $V_{\mathrm{w}}$. The latter correlation may be expected because the increase of the longitudinal length of the penetrant molecule requires longer EH for accommodation which has longitudinal length proportional to that of the penetrant molecule. Here the cross-sectional area of the penetrant was assumed to remain constant with increasing molecular length.

It is worth noting that $\Delta V^{\ddagger}$ for diffusion as compared at the same molecular volume of the penetrant differs significantly for the azo and the anthraquinone derivatives. This means that not only $V$, the total volume, but some shape factor 
of the penetrant molecules works effective in determining $\Delta V^{\ddagger}$, provided, of course, any physicochemical interactions between the penetrant and the macromolecule are tentatively not considered. The molecules of the anthraquinone derivatives listed in Table I are all rigid molecules, having no flexible parts in the structure; the ratios of the length to the width for them are about $3: 2$. On the other hand, the molecules of the azo derivatives have the azo bridges which are supposed to have flexibility to some extent because the conjugation energy between the azo group and the phenyl rings will not be sufficient to hold the completely flat conformation between the azo group and the phenyl rings ${ }^{10)}$. The ratio between length and width is more or less larger for the azo derivatives than for the anthraquinone derivatives. The difference between these shape characteristics of the penetrants of the azo and the anthraquinone derivatives suggest that a rigid and "fat" penetrant needs larger $\Delta V^{+}$than a flexible and "slim" penetrant compared at the same molecular volume. Probably, such correlation must have regards with the long chain molecules consisting the polymer matrix in which the penetrant molecule diffuses. Since the $\Delta V^{*}$, in itself, arises from the effects of pressure and volume, it should not contain any "shape" effect. However, the dead space produced from the packing of the penetrant molecule and the surrounding polymer chains suffers such shape effect. It is likely that the dead space produced from the packing of the penetrant and the long polymer segment will be smaller for the azo derivatives, which are as slim as the PET segment, than for the anthraquinone derivatives which are fat and will make more dead space when packed with the polymer chains.

Finally, it is interesting to note that Sakai, Miyasaka and Ishikawa reported similar results ${ }^{17)}$ on the diffusion of disperse dyes in PET sheet under zero pressure by the sublimation method. These authors concluded that the anthraquinone derivatives needed larger critical free volumes for diffusion than the azo derivatives compared at the same molecular weight. It seems significant that the studies by means of different experimental methods led to essentially the same conclusion on the $\mathrm{EH}$ space for the diffusion of the azo and the anthraquinone derivatives.
Acknowledgment: The authors are sincerely grateful to Dr. T. Okubo of Ise Laboratory, Kyoto University, for many valuable suggestions and discussions on $\Delta V^{\ddagger}$. They also acknowledge support for this research by a grant (\#549019) from the Ministry of Education, Japan. Part of the contents of this paper was read before the 23rd Discussion Meeting for Chemistry of Dyeing held in Tokyo on June 22-23, 1981.

\section{References}

1) T. Ito, J. Seta, H. Urakawa and S. Fujita, Sen-i Gakkaishi, 37, T-119 (1981).

2) S. D. Hamann, "Physico-Chemical Effects of Pressure", Butterworths, London, 1957, Chap. 5.

3) R. A. Assink, J. Polym. Sci., Polym. Phys. Ed., 15, 227 (1977).

4) R. C. Koeller and H. G. Drickamer, J. Chem. Phys., 21, 267 (1953).

5) E. I. Valko, "Man-Made Fibers", Vol. 3, Interscience, New York, 1962, Chap. 4.

6) F. Bueche, "Physical Properties of Polymers", Interscience, New York, 1968, pp. 533-570.

7) J. Seta and T. Ito, Sen-i Gakkaishi, 38, T-178 (1982).

8) T. Ito, J. Seta, H. Urakawa and S. Fujita, 22nd Discussion Meeting for Chemistry of Dyeing, Tokyo, 1980, Preprints 32.

9) T. Ito, J. Seta and H. Urakawa, Annual Meeting of the Soc. Fiber Sci. Technol. Japan, Tokyo, 1980, Preprints 164.

10) A. I. Kitaigorodskii, "Organic Chemical Crystallography', Consultants Bureau, New York, 1961.

11) L. Pauling, "The Chemical Bond", Cornell University Press, 1967, Chap. 7.

12) T. Ito, J. Seta, H. Urakawa and S. Fujita, Sen-i Gakkaishi, 37, T-103 (1981).

13) R. de P. Daubeny, C. W. Bunn and C. J. Brown, Proc. Roy. Soc. (London), A226, 531 (1954).

14) L. E. Alexander, " $X$-Ray Diffraction Methods in Polymer Science", Interscience, New York, 1969.

15) F. Horii, H. Yamagishi, R. Kitamaru and K. Konishi, Polymer Prep., Japan, 27, 1644 (1978); A. Hirai, F. Horii, R. Kitamaru and T. Suzuki, Polymer Prep., Japan, 30, 2002 (1981).

16) J. H. Dumbleton, J. P. Bell and T. Murayama, J. Appl. Polym. Sci. 12, 2491 (1968).

17) T. Sakai, K. Miyasaka and K. Ishikawa, Sen-i Gakkaishi, 30, T-571 (1974). 


\title{
ポリエチレンテレフタレートに対する 染料分子の拡散の活性化体積
}

\begin{abstract}
京都工芸瀻維大学工芸学部勢田二郎，伊藤泰輔
ポリエチレンテレフタレート皮膜に対する9 種の精製 分散染料の $130^{\circ} \mathrm{C}$ での水溶液加らの拉散俰数 $(D)$ を， 1 $\mathrm{kbar}$ までの高王下に执いて多層膜法之俣野の解析法を 用いて測定した。Dは长力の增加汇上り鋭敏汇減少し， $\ln D$ vs. $P$ プロットの直線の勾配より拉散の活性化体皘 $\left(\Delta V^{\ddagger}\right)$ を得ることができた。たとえば p-nitroaniline およびC.I. Disperse Blue 1に対し， $\Delta V^{\ddagger}$ の値はそれ ぞれ 64 拈よひ123各 $\mathrm{cm}^{8} / \mathrm{mol}$ であった。一方，用いた 染料分子のフィン・デル・ワールス接触模型の平面シル

エット図を作図し，その面皘汇厚さ $3.49 \AA$ を乗じて各染 料分子の容皘 $\left(V_{\mathrm{w}}\right)$ を計算した。 $\Delta V^{\ddagger} と V_{\mathrm{w}}$ との関保を

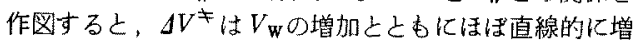
加することが認められた。しかしアジ柔染料とアントラ キノン系染料とで果なる直線関保か得られ，後者住対し 直線はより大きな勾配を与える。以上の結果老，まず得 られた $\Delta V^{\mp}$ の数值そのものについて应散の活性化状態 の観点より吟味し，その知見に基づき，上述の $\Delta V^{\ddagger}$ と $V_{\mathrm{w}}$ との関係について考察を試みた。
\end{abstract}

